\title{
SISTEM INFORMASI GEOGRAFIS DAERAH HORTIKULTURA (SAYURAN) KABUPATEN MALANG
}

\author{
Ahmad Fahim Aslamsyah, Yosep Agus Pranoto, Renaldi Primaswara P \\ Program Studi Teknik Informatika S1, Fakultas Teknologi Industri \\ Institut Teknologi Nasional Malang, Jalan Raya Karanglo km 2 Malang, Indonesia \\ fahimaslamsyah@gmail.com
}

\begin{abstract}
ABSTRAK
Sistem Informasi Geografis (SIG) merupakan sistem informasi modern yang efektif digunakan untuk membuat peta dan mengintegrasi informasi. Untuk saat ini Dinas Tanaman Pangan, Hortikultura dan Perkebunan Kabupaten Malang masih mengalami kesulitan memantau sayur-sayuran di Kabupaten Malang karena luasnya wilayah dan belum ada sistem yang terkomputerisasi untuk dapat membantu pendataan hasil panen sayur-sayuran.

Sistem yang dibangun yaitu sebuah sistem informasi geografis daerah hortikultura sayuran kabupaten malang, peta pada sistem ini dibuat menggunakan ArcGis 10.6 dan Qgis dalam hal ini dengan adanya sistem informasi geografis ini langkah kedepannya akan lebih mempermudah untuk melihat informasi daerah hortikultura sayuran yang sudah ada maupun yang belum ada di kecamatan tersebut.

Berdasarkan hasil dari pengujian pembangunan Sistem Informasi Geografis yang telah selasai dilakukan menyatakan bahwa hasil dari program yang telah dibuat memiliki hasil yang sesuai, hal tersebut dapat di buktikan dengan aplikasi sistem informasi geografis Kabupaten Malang sudah mampu memberikan informasi diantaranya daerah penghasil sayuran, luas perkebunan, jumlah produksi atau hasil panen per tahun. Hasil untuk pengujian black-box yaitu pengujian terhadap cara kerja program dan pengujian fungsional sistem dengan akses sebagai admin dan user sesuai dengan fungsinya pada browser Google Chrome, Mozila Firefox dan Microsoft Edge.
\end{abstract}

Kata Kunci : Sistem Informasi Geografis, Hortikultura Sayuran, Kabupaten Malang

\section{PENDAHULUAN}

Wilayah Kabupaten Malang secara geografis terletak pada koordinat $112^{\circ} 17^{\prime}$ sampai $112^{\circ} 57^{\prime}$ Bujur Timur dan $7^{\circ} 44^{\prime}$ sampai $8^{\circ} 26^{\prime}$ Lintang Selatan Kabupaten Malang memiliki luas wilayah sebesar $3530,35 \mathrm{~km}^{2}$ yang terbagi menjadi 33 Kecamatan antara lain yaitu Kecamatan Ampelgading, Bululawang, Dau, Donomulyo, Gedangan, Gondanglegi, Jabung, Kalipare, Karangploso, Kasembon, Kepanjen, Kromengan, Lawang, Ngajum, Ngantang, Pagak, Pagelaran, Pakis, Pakisaji, Poncokusumo, Pujon, Sumbermanjing Wetan, Singosari, Sumberpucung, Tajinan, Tirtoyudo, Tumpang, Wagir, Wajak, Wonosari. Dari seluruh Kecamatan dalam Kabupaten Malang terdapat daerah perkebunan sayur yang dikelola oleh Dinas Tanaman Pangan, Hortikultura dan Perkebunan Kabupaten Malang.

Untuk saat ini Dinas Tanaman Pangan, Hortikultura dan Perkebunan Kabupaten Malang masih mengalami kesulitan memantau sayur-sayuran di Kabupaten Malang karena luasnya wilayah dan belum ada sistem yang terkomputerisasi untuk dapat membantu pendataan hasil panen sayur-sayuran. Hal ini dikarenakan luasnya wilayah yang ada pada Kabupaten Malang. Kabupaten Malang masih menggunakan cara yang lama berbentuk laporan. Penelitian ini dilakukan guna untuk mencari solusi dalam mengembangkan teknologi informasi di Kabupaten Malang.
Dari permasalahan diatas maka dibangun sebuah sistem informasi geografis, dengan adanya sistem informasi geografis ini diharapkan lebih mudah dan membantu pemerintah (Dinas Tanaman Pangan, Hortikultura dan Perkebunan) dalam melakukan pemantauan dari berbagai jenis sayur-sayuran maupun dari berbagai kecamatan dalam Kabupaten Malang. Adapun juga untuk mempermudah masyarakat yang ingin mengetahui informasi mengenai letak daerah hortikultura (sayuran) yang ada pada Kabupaten Malang. Oleh karena itu Sistem Informasi Geografis merupakan sistem yang dirancang untuk bekerja dengan data yang tereferensi secara spasial atau koordinat-koordinat geografis dan disusun berdasarkan analisis kebutuhan dan perancangan yang terstruktur sehingga tercapai tujuan dari pembuatan.

\section{TINJAUAN PUSTAKA}

\subsection{Penelitian Terdahulu}

Sistem Informasi Geografis (SIG) merupakan salah satu sarana untuk penyampaian informasi terutama untuk informasi-informasi yang berhubungan dengan data spasial dan data pendukung penyampaian informasi lainnya. Penerapan Sistem Informasi Geografis (SIG) merupakan langkah yang tepat untuk pemetaan daerah penentuan peruntukan lahan pertanian. Telah diakui Sistem Informasi Geografis (SIG) mempunyai kemapuan yang sangat luas, baik dalam proses pemetaan dan analisa 
sehingga teknologi sering dipakai dalam proses perencanaan tata ruang. Teknologi GIS mengintegrasikan operasi pengolahan data berbasis database yang biasa digunakan saat ini, seperti pengambilan visualisasi yang khas serta berbagai keuntungan yang mampu ditawarkan analisis geografis melalui gambar-gambar petanya berbasis web.[1]

Tantangan dalam pengelolaan pertanian di Indonesia menuntut pengelolaan khusus untuk penguasaan di bidang teknologi dalam pemetaan luas lahan sawah. Bahkan belum semua petani yang dapat melakukan pengelolaan pertanian di bidang teknologi. Untuk mengatasi tantangan dan ancaman pertanian padi, maka solusi yang tepat yaitu membuat sebuah sistem informasi geografis. Dengan adanya sistem informasi geografis berbasis web dapat memberikan informasi pemetaanterkait luas lahan dan potensi tanaman padi. Dari hasil penelitian menunjukkan sistem informasi geografis dapat memberikan informasi bentuk pop-up pada peta dan pemantauan lahan tanaman padi.[2]

Ulfiah, Peta dan pemetaan sangat dibutuhkan dalam berbagai bidang. Dalam dunia pertanian, salah satu permasalahan yang sering terjadi adalah adanya kurangnya pengetahuan akan persebaran tentang pertanian. Hal tersebut disebabkan oleh adanya dukungan teknologi informasi khususnya dibidang SIG yang belum menjangkau bidang pertanian di beberapa daerah terpencil atau daerah yang baru berkembang. Misalnya saja di Kabupaten Gorontalo, informasi tentang sebaran pertanian hanya dalam bentuk pencatatan data, yang kemudian diolah kedalam buku atau artikel. Jika pemerintah sadar akan gunanya pengolahan peta dan pemetaan menggunakan teknologi informasi, maka akan lebih efektif dan akurat persebaran informasi akan sebaran Pertanian di Kabupaten Gorontalo.[3]

Melihat keadaan potensi tanaman pangan Kabupaten halmahera barat cukup signifikan dan merupakan salah satu potensi dijadikan penunjang perekonomian kabupaten Halmahera Barat maka untuk mengatasi permasalahan ini, perencanaan spasial sangat berperan. SIG (Sistem Informasi Geografi) merupakan langkah yang tepat untuk mengetahui dan menginformasikan lokasi potensi tanaman pangan kabupaten halmahera barat. Karena telah diakui SIG (Sistem Informasi Geografi) mempunyai kemampuan yang sangat luas, baik dalam proses pemetaan dan analisis sehingga teknologi tersebut sering dipakai dalam proses perencanaan tata ruang. Dengan memanfaatkan mapserver sebagai tools untuk menampilkan media peta yang informatif dan interaktif berbasis website sehingga dapat menyajikan data dalam bentuk peta digital, tabel informasi dan grafik (chart).[4]

Mayoritas pencaharian utama penduduknya adalah bermata pencaharian sebagai petani. Pada setiap wilayah Kabupaten Lima Puluh Kota banyak di kelilingi dengan lokasi pertanian terutama pada tanaman padi dan cabe kriting. Pada saat ini cara pemasaran dari padi dan cabe ini adalah dengan mengantarkan langsung ke pasar yang ada di kota payakumbuh yang akan didistribusikan ke konsumen di kota kota di sumatra barat dan juga kepada provinsi tetangga seperti riau jambi dan palembang dan untuk padi yang sudah digiling menjadi beras sering kali di distribusikan ke seluruh kota di sumatra dan juga pulau jawa, hal ini untuk memenuhi kebutuhan Rumah Makan Padang yang ciri khas nasi nya yang berderai. Untuk memudahkan pemasaran padi dan cabe pada waktu panennya di bangulah sebuah aplikasi sistem informasi geografis produksi mulai dari per Nagari atau Desa dan kecamatan. Dengan aplikasi ini dapat membantu membantu Dinas Pertanian dan para agen-agen yang ingin mencari lokasi produksi padi dan cabe kriting. kesulitan bagi para agen dan Dinas Pertanian, dalam mencari produksi padi dan cabe kriting yang banyak di setiap lokasi wilayah, di karenakan banyaknya lokasi tanaman pertanian yang terpencil membuat kesulitan dalam mendapatkan informasi tentang produksi padi dan cabe kriting.[5]

Informasi data sekarang ini masih disajikan dalam bentuk laporan statistik setiap tahunnya di setiapsetiap daerah. Dalam hal ini termasuk juga pada wilayah Kabupaten Kediri. Untuk saat ini Dinas Pertanian dan Perkebunan Kabupaten Kediri masih mengalami kesulitan memantau pertanian di Kabupaten Kediri karena luasnya wilayah dan belum ada sistem yang dapat membantu pendataan lahan pertanian dan hasil produksi tanaman pangan. Dalam hal ini dengan adanya teknologi informasi ini langkah kedepannya akan lebih mempermudah untuk melihat lahan jenis tanaman pangan yang sudah ada maupun yang belum ada di suatu kecamatan tersebut. Penerapan sistem informasi geografis ini bermanfaat untuk memberikan informasi letak wilayah-wilayah kecamatan dari Kabupaten Kediri serta mengetahui beberapa lahan jenis tanaman yang terdapat di Kecamatan tersebut, dan memberikan informasi produksi hasil panennya dari tiap-tiap Kecamatan.[6]

\subsection{Dasar Teori}

\subsubsection{Sistem Informasi Geografis}

SIG adalah sistem yang berbasiskan komputer (CBIS) yang digunakan untuk menyimpan dan memanipulasi informasi-informasi geografis. SIG dirancang untuk mengumpulkan, menyimpan, dan menganalisis objek-objek dan fenomena di mana lokasi geografis merupakan karakteristik yang penting atau kritis untuk dianalisis. Dengan demikian, SIG merupakan sistem komputer yang memiliki empat kemampuan berikut dalam menangani data yang bereferensi geografis: masukan, manajemen data (penyimpanan dan pemanggilan data), analisis dan manipulasi data, dan keluaran.[7] 


\subsubsection{Data Vektor}

Dengan menggunakan model vektor, objekobjek dan informasi di permukaan bumi dilambangkan sebagai titik, garis, atau poligon. Masing-masing mewakili tipe objek tertentu sebagaimana dijelaskan sebagai berikut : Titik (point) : merepresentasikan objek spasial yang tidak memiliki dimensi panjang dan/atau luas. Fitur spasial direpresentasikan dalam satu pasangan koordinat $\mathrm{x}, \mathrm{y}$. Contohnya stasiun curah hujan, titik ketinggian, observasi lapangan, titik-titik sampel.

Garis (line/segment) : merepresentasikan objek yang memiliki dimensi panjang namun tidak mempunyai dimensi area, misalnya jaringan jalan, pola aliran, garis kontur.

Poligon : merepresentasikan fitur spasial yang memiliki area, contohnya adalah unit administrasi, unit tanah, zona penggunaan lahan.titik sampel. Data Titik, Garis, dan Luasan dalam Vektor ditunjukkan pada Gambar 1.

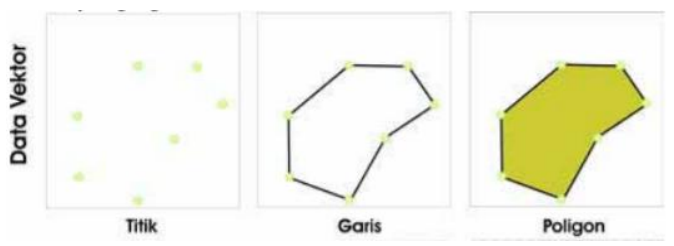

Gambar 1 Data Titik, Garis, dan Luasan dalam Vektor

\subsubsection{Data Raster}

Model data raster menampilkan, menempatkan, dan menyimpan data spasial dengan menggunakan struktur matriks atau piksel-piksel yang membentuk grid (bidang referensi horizontal dan vertikal yang terbagi menjadi kotak-kotak). Piksel adalah unit dasar yang digunakan untuk menyimpan informasi secara eksplisit. Setiap piksel memiliki atribut tersendiri, termasuk koordinatnya yang unik. Akurasi model ini sangat tergantung pada resolusi atau ukuran piksel suatu gambar. Model raster memberikan informasi spasial apa saja yang terjadi di mana saja dalam bentuk gambaran yang digeneralisasi. Dengan model raster, data geografi ditandai oleh nilai-nilai elemen matriks dari suatu objek yang berbentuk titik, garis, maupun bidang[8]. Data Titik, Garis, dan Luasan dalam Raster ditunjukkan pada Gambar 2.

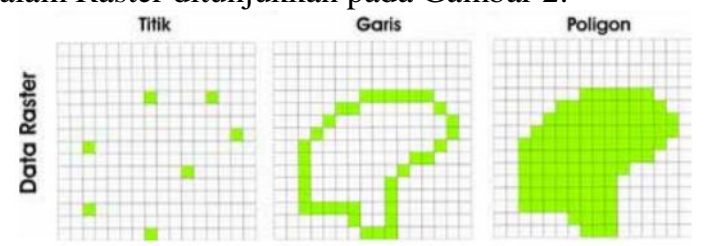

Gambar 2 Data Titik, Garis, dan Luasan dalam Raster

\section{METODE PENELITIAN}

\subsection{Analisis Sistem}

Sistem yang dibangun pada sistem informasi geografis di Kabupaten Malang ini merupakan sistem untuk menginformasikan daerah penanam sayursayuran serta menginformasikan jumlah produksi pertahun dengan menggunakan Sistem Informasi Geografis pada website. Sehingga untuk dibangunnya sistem ini, dibutuhkan data-data serta informasi hasil produksi sayur-sayuran.

\subsection{Desain Arsitektur Sistem}

Dalam Sistem Informasi Geografis Daerah Hortikultura Sayuran Kabupaten Malang, dilakukan pemetaaan daerah berdasarkan Kecamatan dari Kabupaten Malang, Terlihat pada Gambar 3.

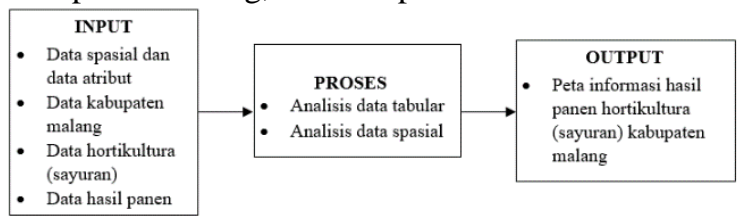

Gambar 3 Desain Arsitektur Sistem

\subsection{Flowchart SIG}

Berikut merupakan flowchart SIG dari sistem informasi geografis daerah hortikultura (sayuran) Kabupaten Malang seperti ditunjukkan pada Gambar 4.

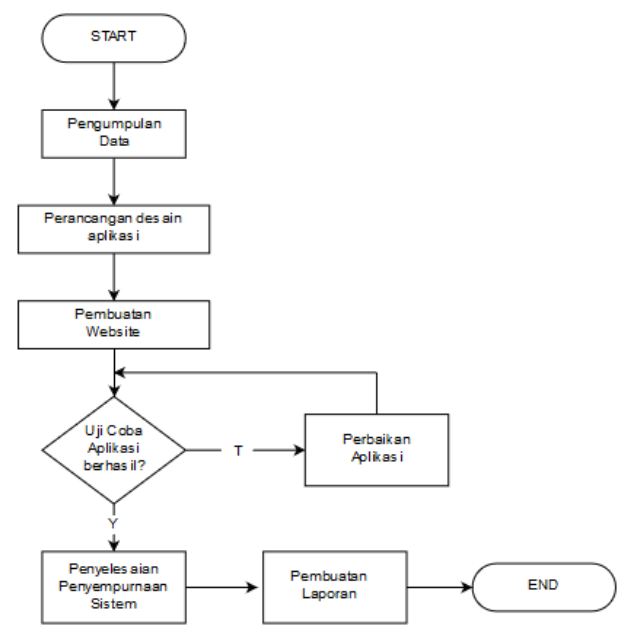

Gambar 4 Flowchart SIG

\subsection{Flowchart Sistem Admin}

Flowchart sistem ini menjelaskan proses berjalannya aplikasi pada admin seperti ditunjukkan pada Gambar 5. 


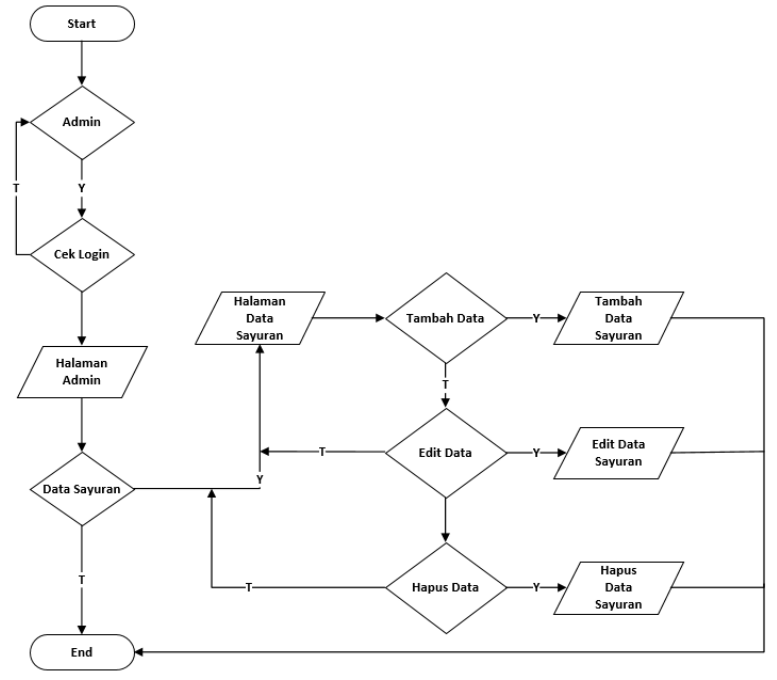

Gambar 5 Flowchart Sistem Admin

\subsection{Flowchart Sistem User}

Flowchart sistem ini menjelaskan proses berjalannya aplikasi pada user seperti ditunjukkan pada Gambar 6.

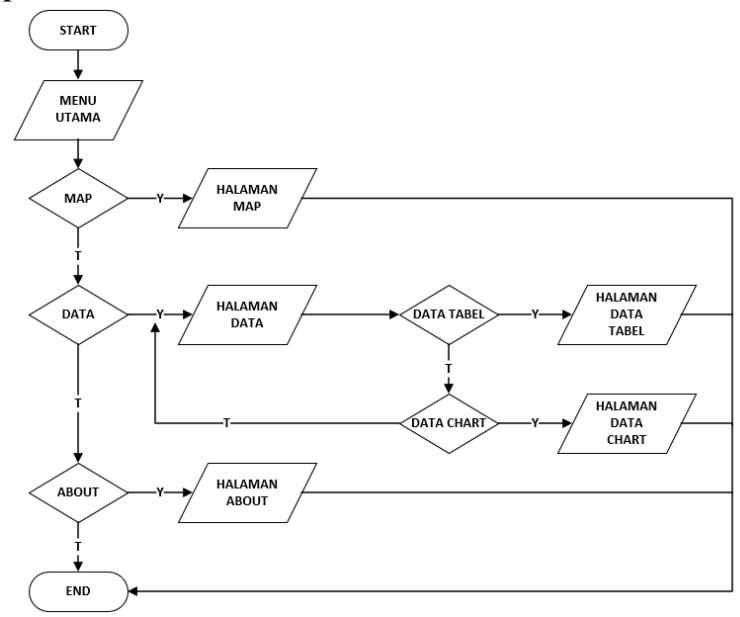

Gambar 6 Flowchart Sistem User

\subsection{Perancangan Database}

1. Tabel Admin

Tabel admin merupakan tabel yang digunakan untuk menyimpan data user. Tabel admin ditunjukkan pada Tabel 1.

Tabel 1 Struktur Tabel Admin

\begin{tabular}{|c|l|c|}
\hline No & \multicolumn{1}{|c|}{ Name } & Type \\
\hline 1 & Username & Varchar (30) \\
\hline 2 & Password & Varchar (20) \\
\hline
\end{tabular}

2. Tabel Data Hortikultura Sayuran

Tabel ini berfungsi untuk menyimpan data atribut jenis sayuran dan informasi hasil panen yang ada pada Kabupaten Malang. Deskripsi tabel dapat dilihat pada Tabel 2.
Tabel 2 Struktur Tabel Sayuran

\begin{tabular}{|c|l|c|}
\hline No & \multicolumn{1}{|c|}{ Name } & Type \\
\hline 1 & No & Int (11) \\
\hline 2 & Kecamatan & Text \\
\hline 3 & Jenis Sayuran & Text \\
\hline 4 & Luas (Ha) & Varchar (20) \\
\hline 5 & Produksi (Ton) & Varchar (20) \\
\hline
\end{tabular}

\section{HASIL DAN PEMBAHASAN}

\subsection{Halaman Home}

Tampilan halaman home yang diakses oleh user/pengguna sehingga tidak perlu melakukan Login terlebih dahulu. Halaman ini menunjukan halaman utama pada websiite sistem informasi geografis daerah hortikultura sayuran Kabupaten malang, Tampilannya seperti Gambar 7.

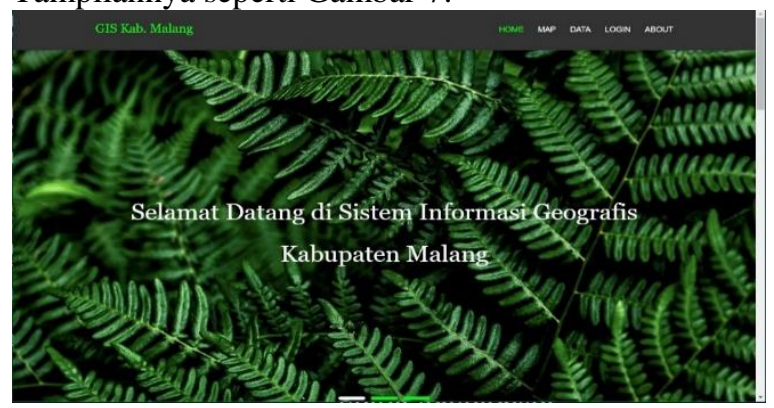

Gambar 7 Halaman Home

\subsection{Halaman Map Kabupaten Malang}

Tampilan halaman map, menunjukkan informasi daerah beserta informasi sayuran yang berada pada tiap-tiap Kecamatan di Kabupaten Malang. Tampilan informasi berisi tentang kecamatan, jenis sayuran, luas(ha) dan produksi(ton) pertahun, tampilan peta seperti pada Gambar 8

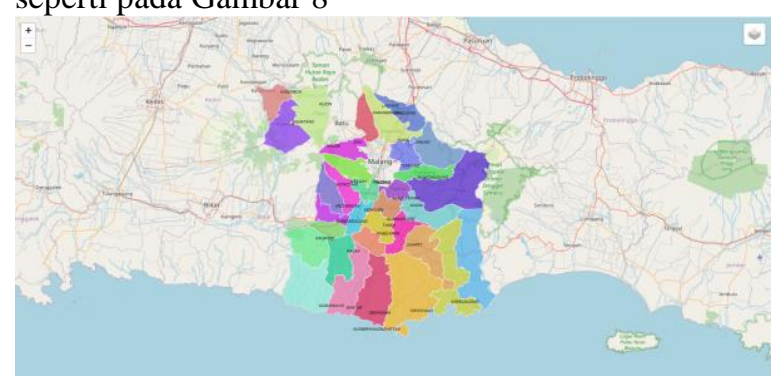

Gambar 8 Halaman Map Kabupaten Malang

\subsection{Persebaran Sayuran}

Sebaran jenis-jenis sayuran di berbagai kecamatan, tampilan peta seperti pada Gambar 9.

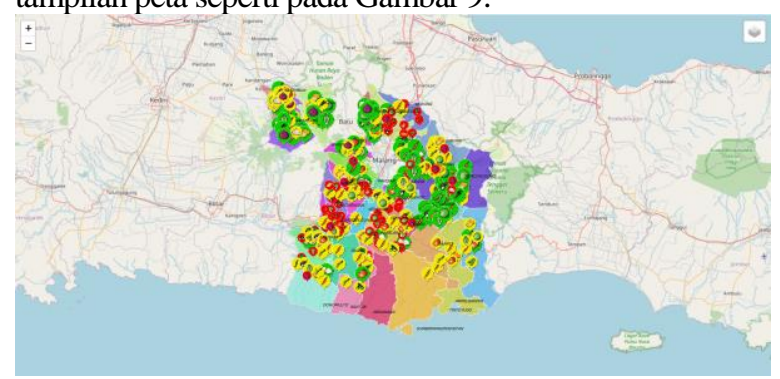

Gambar 9 Sebaran berbagai jenis sayuran 


\subsection{Halaman Informasi Data Sayuran}

Halaman data sayuran berisi list data-data sayuran, luas, produksi perkecamatan. Seperti pada Gambar 10

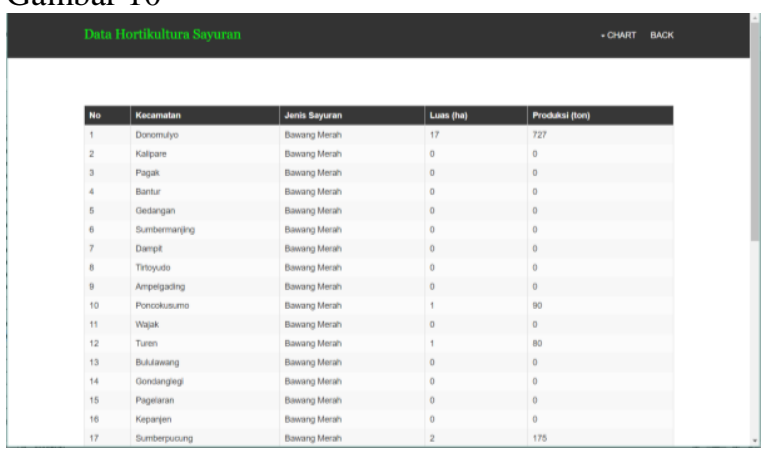

Gambar 10 Informasi data sayuran

\subsection{Halaman Informasi Chart Data Sayuran}

Halaman chart data sayuran merupakan halaman yang berisikan chart dari data sayuran di Kabupaten Malang, chart dalam bentuk combobox dikarenakan chart yang ditampilan yaitu dalam jenis yang berbeda, pada tampilan dibawah merupaka chart jenis sayuran, pada chart ini, hasil panen tertinggi yaitu kecamatan ngajum seperti pada Gambar 11.

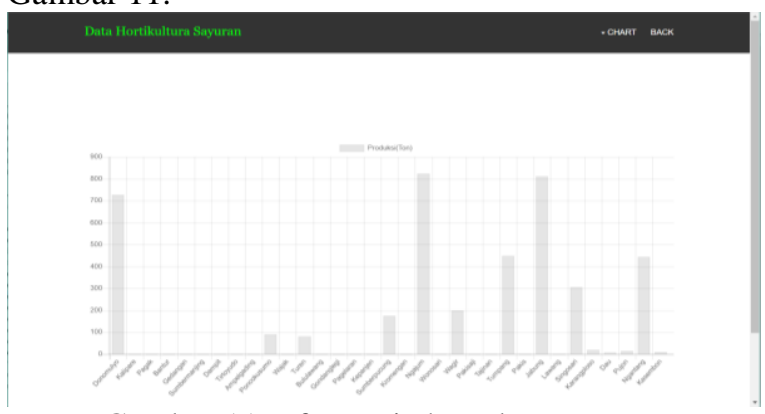

Gambar 11 Informasi chart data sayuran

\subsection{Halaman Login Admin}

Halaman ini digunakan admin untuk melihat data, mengubah dan menghapus data sayuran. Sebelum mengolah data admin harus melewati proses login terlebih dahulu pada halaman login Berikut tampilan halaman login admin pada Gambar 12.
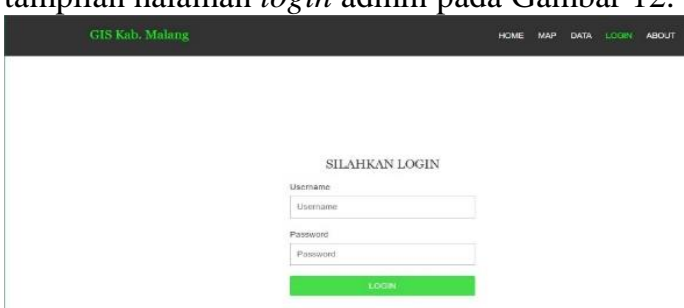

\section{Gambar 12 Halaman Login Admin}

\subsection{Halaman List Data Sayuran Admin}

Halaman ini berisi daftar data sayuran yang telah dimasukkan oleh admin. Dalam bagian action admin bisa memilih untuk mengubah dan menghapus data, tampilan dapat dilihat pada Gambar 13.

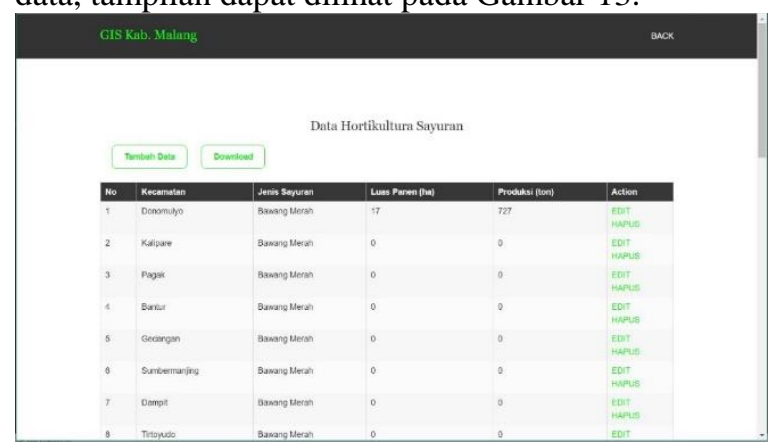

Gambar 13 Halaman List Data Sayuran

\subsection{Halaman Tambah Data Sayuran}

Halaman ini berisi form untuk menambah data sayuran. Data yang ditambahkan adalah kode, kecamatan,jenis sayuran, luas (ha),dan produksi (ton). tampilan dapat dilihat pada Gambar 14.

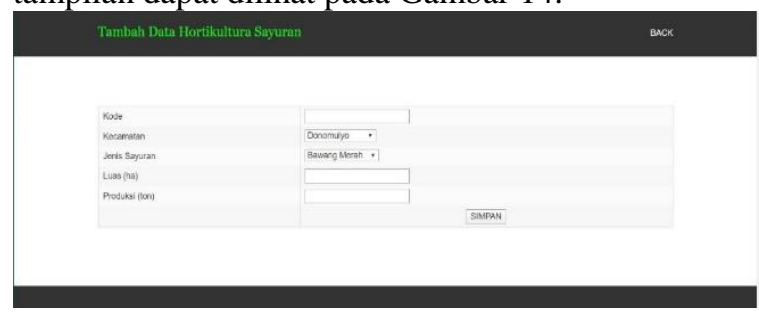

Gambar 14 Halaman Tambah Data

\subsection{Halaman Ubah/Edit Data Sayuran}

Halaman edit data sayuran berfungsi untuk mengubah data yang ada pada list data sayuran seperti Gambar 15.

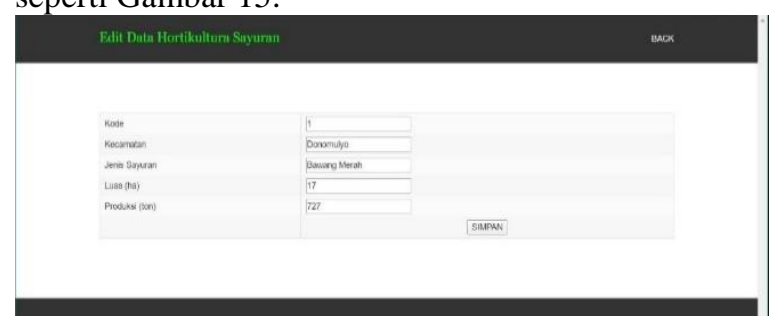

Gambar 15 Halaman Ubah/Edit Data

\subsection{Halaman About}

Halaman ini berisi data sipembuat aplikasi, tampilan dapat dilihat pada Gambar 16.

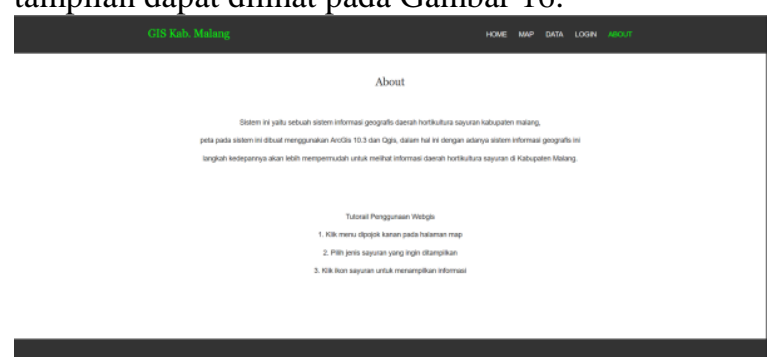

Gambar 16 Halaman About

\subsection{Pengujian Fungsional Sistem}

Pengujian sistem merupakan proses menampilkan sistem dengan maksud untuk 
menemukan adanya kesalahan atau tidak pada sistem sebelum sistem dipublikasikan untuk digunakan oleh masyarakat. Hasil pengujian sistem ditunjuakkan pada Tabel 3 sebagai berikut.

Tabel 3 Pengujian Fungsional

\begin{tabular}{|c|c|c|c|c|}
\hline \multirow[b]{2}{*}{ No } & \multirow[b]{2}{*}{ Item Yang Di Uji } & \multicolumn{3}{|c|}{ Nama Browser } \\
\hline & & $\begin{array}{l}\text { Mozila } \\
\text { Firefox }\end{array}$ & $\begin{array}{l}\text { Google } \\
\text { Chrome }\end{array}$ & $\begin{array}{l}\text { Microsoft } \\
\text { Edge }\end{array}$ \\
\hline 1 & $\begin{array}{l}\text { Halaman Utama } \\
\text { Website }\end{array}$ & $\checkmark$ & $\checkmark$ & $\checkmark$ \\
\hline 2 & $\begin{array}{l}\text { Halaman Peta } \\
\text { Website }\end{array}$ & $\checkmark$ & $\checkmark$ & $\checkmark$ \\
\hline 3 & $\begin{array}{l}\text { Halaman Data } \\
\text { Sayuran }\end{array}$ & $\checkmark$ & $\checkmark$ & $\checkmark$ \\
\hline 4 & $\begin{array}{l}\text { Halaman } \\
\text { Tampilan Chart }\end{array}$ & $\checkmark$ & $\checkmark$ & $\checkmark$ \\
\hline 5 & Halaman Admin & $\checkmark$ & $\checkmark$ & $\checkmark$ \\
\hline 6 & Halaman About & $\checkmark$ & $\checkmark$ & $\checkmark$ \\
\hline
\end{tabular}

Keterangan :

$\sqrt{ }=$ Berjalan

$\mathrm{x}=$ Tidak Berjalan

\subsection{Pengujian Black-Box}

Rencana pengujian yang akan dilakukan dengan menguji sistem menggunakan metode black-box.

Tabel 4 Pengujian Menggunakan Black-Box

\begin{tabular}{|c|c|c|c|c|}
\hline No & Butir uji & $\begin{array}{l}\text { Hasil yang } \\
\text { diharapkan }\end{array}$ & $\begin{array}{c}\text { Hasil } \\
\text { sebenarnya }\end{array}$ & Hasil \\
\hline 1 & $\begin{array}{l}\text { Halaman } \\
\text { home }\end{array}$ & $\begin{array}{c}\text { Masuk ke } \\
\text { halaman home }\end{array}$ & $\begin{array}{c}\text { Masuk ke } \\
\text { halaman } \\
\text { home }\end{array}$ & Sesuai \\
\hline 2 & $\begin{array}{l}\text { Halaman } \\
\text { Peta }\end{array}$ & $\begin{array}{l}\text { Proses } \\
\text { menampilkan } \\
\text { data peta, pop up } \\
\text { dan ikon sesuai } \\
\text { kategori jenis, } \\
\text { warna, dan } \\
\text { produksi sayuran }\end{array}$ & $\begin{array}{l}\text { Data peta, } \\
\text { pop up dan } \\
\text { ikon telah } \\
\text { tampil pada } \\
\text { halaman peta }\end{array}$ & Sesuai \\
\hline 3 & $\begin{array}{l}\text { Halaman } \\
\text { data user }\end{array}$ & $\begin{array}{l}\text { Menampilkan } \\
\text { data sayuran }\end{array}$ & $\begin{array}{l}\text { Data telah } \\
\text { tampil pada } \\
\text { halaman data } \\
\text { sayuran user } \\
\end{array}$ & Sesuai \\
\hline 4 & $\begin{array}{l}\text { Halaman } \\
\text { data chart }\end{array}$ & $\begin{array}{l}\text { Menampilkan } \\
\text { data chart sayuran }\end{array}$ & $\begin{array}{l}\text { Data telah } \\
\text { tampil pada } \\
\text { halaman data } \\
\text { chart }\end{array}$ & Sesuai \\
\hline 5 & $\begin{array}{l}\text { Login } \\
\text { Admin }\end{array}$ & $\begin{array}{lr}\text { Proses } & \text { mengisi } \\
\text { data } & \text { login, } \\
\text { verifikasi } & \\
\text { username } & \text { dan } \\
\text { password } & \\
\end{array}$ & $\begin{array}{l}\text { Verifikasi } \\
\text { username } \\
\text { dan password }\end{array}$ & Sesuai \\
\hline 6 & $\begin{array}{l}\text { Halaman } \\
\text { admin }\end{array}$ & $\begin{array}{l}\text { Masuk ke } \\
\text { halaman admin }\end{array}$ & $\begin{array}{l}\text { Masuk ke } \\
\text { halaman } \\
\begin{array}{l}\text { admin data } \\
\text { sayuran }\end{array} \\
\end{array}$ & Sesuai \\
\hline 7 & $\begin{array}{l}\text { Halaman } \\
\text { data } \\
\text { sayuran } \\
\text { admin } \\
\end{array}$ & $\begin{array}{l}\text { Data yang telah di } \\
\text { inputkan pada } \\
\text { Form halaman } \\
\text { data sayuran }\end{array}$ & $\begin{array}{l}\text { Data telah } \\
\text { tampil pada } \\
\text { halaman data } \\
\text { sayuran }\end{array}$ & Sesuai \\
\hline 8 & $\begin{array}{l}\text { Halaman } \\
\text { tambah } \\
\text { data } \\
\text { sayuran }\end{array}$ & $\begin{array}{l}\text { Proses } \\
\text { pemasukan data } \\
\text { sayuran data yang } \\
\text { baru tersimpan di } \\
\text { database }\end{array}$ & $\begin{array}{l}\text { Data berhasil } \\
\text { di simpan di } \\
\text { database }\end{array}$ & Sesuai \\
\hline 9 & Halaman & Proses mengubah & Proses & Sesuai \\
\hline
\end{tabular}

\begin{tabular}{|c|c|c|c|c|}
\hline No & Butir uji & $\begin{array}{l}\text { Hasil yang } \\
\text { diharapkan }\end{array}$ & $\begin{array}{c}\text { Hasil } \\
\text { sebenarnya }\end{array}$ & Hasil \\
\hline & $\begin{array}{l}\text { edit data } \\
\text { sayuran }\end{array}$ & $\begin{array}{l}\text { data sayuran yang } \\
\text { sudah ada di } \\
\text { dalam database }\end{array}$ & $\begin{array}{l}\text { perubahan } \\
\text { data berhasil }\end{array}$ & \\
\hline 10 & $\begin{array}{l}\text { Tombol } \\
\text { hapus } \\
\text { data } \\
\text { sayuran }\end{array}$ & $\begin{array}{l}\text { Proses } \\
\text { menghapus data } \\
\text { sayuran di dalam } \\
\text { database }\end{array}$ & $\begin{array}{l}\text { Proses hapus } \\
\text { data berhasil }\end{array}$ & Sesuai \\
\hline 11 & $\begin{array}{l}\text { Tombol } \\
\text { download } \\
\text { data } \\
\text { sayuran }\end{array}$ & $\begin{array}{lr}\text { Proses } & \text { download } \\
\text { data } & \text { sayuran dan } \\
\text { akan } & \text { disimpan } \\
\text { dalam } & \text { bentuk } \\
\text { excel } & \\
\end{array}$ & $\begin{array}{l}\text { Data berhasil } \\
\text { di download } \\
\text { dalam bentuk } \\
\text { excel }\end{array}$ & Sesuai \\
\hline 12 & $\begin{array}{l}\text { Tombol } \\
\text { logout } \\
\text { admin }\end{array}$ & $\begin{array}{l}\text { Proses logout } \\
\text { admin }\end{array}$ & $\begin{array}{l}\text { Admin } \\
\text { berhasil } \\
\text { logout }\end{array}$ & Sesuai \\
\hline
\end{tabular}

Berdasarkan hasil pengujian menggunakan metode black-box yang telah dilakukan dapat di ambil kesimpulan bahwa secara fungsional sistem sudah dapat menghasilkan output yang sesuai.

\section{KESIMPULAN DAN SARAN}

\subsection{Kesimpulan}

Berdasarkan hasil dari perancangan dan implementasi dari aplikasi sistem informasi geografis daerah hortikultura sayuran Kabupaten Malang berbasis website maka dapat diambil beberapa kesimpulan yaitu:

1. Berdasarkan hasil dari penelitian maka aplikasi Sistem Informasi Geografis daerah hortikultura sayuran Kabupaten Malang ini dapat disajikan dalam bentuk peta, hal tersebut bertujuan untuk memudahkan dinas dan masyarakat untuk melakukan pendataan informasi sayuran, dan informasi yang berada pada wilayah Kabupaten Malang.

2. Berdasarkan hasil dari pengujian pembangunan Sistem Informasi Geografis dengan menggunakan ArcGis 10.6 telah selasai di lakukan, hal tersebut dapat di buktikan dengan aplikasi sistem informasi geografis Kabupaten Malang sudah mampu memberikan informasi diantaranya daerah sayuran, luas perkebunan, jumlah produksi atau hasil panen per tahun.

3. Berdasarkan hasil pengujian fungsional aplikasi sistem informasi Sistem Informasi Geografis Daerah Sayuran berjalan sesuai dengan apa yang di harapkan, yakni dapat dijalankan pada browser mozila firefox, google chrome dan Microsoft edge.

\subsection{Saran}

Agar dalam aplikasi ini berjalan dengan baik kedepannya, maka ada beberapa hal yang perlu dilakukan yaitu sebagai berikut:

1. Sistem Informasi Geografis Daerah hortikultura sayuran Kabupaten Malang dapat dikembangkan lagi agar menjadi lebih baik. Caranya bias menambahkan dalam bentuk aplikasi android agar 
memudahkan pengguna smartphone langsung 2. mengakses tanpa bantuan aplikasi browser

engembangan aplikasi Sistem Informasi Geografis Daerah Hortikultura Sayuran data yang ada pada peta dapat dirubah, dan tidak berupa data static.

\section{DAFTAR PUSTAKA}

[1] Andik Adi Suryanto, Amaludin Arifia, Asfan Muqtadir and Dwi Kurnia Basuki, 2017. Pemetaan Potensi Lahan Pertanian Di Kabupaten Tuban Berbasis Sistem Informasi Geografis. SAINTEKBU: Jurnal Sains dan Teknologi. Volume 9 No.2.

[2] Adi Tri Soelistio, Tody Ariefianto Wibowo and Agus Ganda Permana, 2015. Aplikasi Sistem Informasi Geografis (Sig) Untuk Pengelolaan Padi Di Pulau Jawa Berbasis Web. eProceedings of Applied Science, Vol.1, No.1, pp. 720-731.

[3] Ulfiah, 2010. Sistem Informasi Geografi Pertanian Kota Bogor Berbasis Web Dengan Menggunakan Quantum GIS, Jtech 2016, 4(2) $116-122$.

[4] Arisandy Ambarita, 2017. Sistem Informasi Geografis Potensi Tanaman Pangan (Studi Kasus : Kabupaten Halmahera Barat Provinsi Maluku Utara). Indonesian Journal on Networking and Security - Volume 6 No 1.

[5] Harison, Fuji Kurniawan, 2017. Aplikasi Sistem Informasi Geografis Produksi Padi dan Cabe di
Kabupaten Lima Puluh Kota Berbasis Android. TEKNOSI, Vol. 03, No. 01

[6] Antonius Septya Priya Pradana, 2019. Sistem Informasi Geografis Penggunaan Lahan Dan Produksi Tanaman Pangan Kabupaten Kediri Jawa Timur. Jurnal Mahasiswa Teknik Informatika. Vol. 3 No. 2.

[7] Prahasta, Eddy. 2009. Sistem Informasi Geografis : Konsep-Konsep Dasar (Perspektif Geodesi \& Geomatika). Bandung: Informatika.

[8] Ekadinata, A. Dewi, S. Hadi, D P. 2008. Sistem Informasi Geografis dan Penginderaan Jauh Menggunakan ILWIS Open Source

[9] Ali Zaki. 2009. Kiat Jitu Membuat Website Tanpa Modal. Jakarta : ElexmediaKomputindo.

[10] Mubyarto. 1995. Pengantar Ekonomi Pertanian. Jakarta : LP3ES.

[11] Wahana Komputer, 2010. Panduan Belajar MySQL Database Server. Media Kita : Jakarta Selatan.

[12] Widodo, Aris Puji, dkk. 2006. Bahan Ajar Pemrograman Internet. Prodi Ilmu Komputer Jurusan Matematika Fakultas MIPA Universitas Diponegoro.

[13] Yeni Kustiyahningsih, Devie Rosa Anamisa. 2011. Pemograman Basis Data Berbasis Web Menggunakan PHP \& MySQL.Graha Ilmu : Yogyakarta.

[14] MADCOM. 2016. Pemrograman PHP dan MySQL Untuk Pemula. Yogyakarta : C.V Andi. 